\title{
Research of problems and prospects of state development in the pedagogical process
}

\section{Pesquisa de problemas e perspectivas de desenvolvimento do Estado no processo pedagógico}

\section{Investigación de problemas y perspectivas de desarrollo estatal en el proceso pedagógico}

\author{
Myroslav Kryshtanovych $^{1}$ iD, Alona Romanova1 ${ }^{1 D}$, Ihor Koval ${ }^{1}$ iD, \\ Nataliia Lesko ${ }^{1}$ iD, Ulyana Lukashevska1 iD \\ ${ }^{1}$ Lviv Polytechnic National University, Lviv, Ukraine. \\ Corresponding author: \\ Myroslav Kryshtanovych \\ Email: nomar7676@ukr.net
}

How to cite: Kryshtanovych, M., Romanova, A., Koval, I., Lesko, N., \& Lukashevska, U. (2021). Research of problems and prospects of state development in the pedagogical process. Revista Tempos e Espaços em Educação, 14(33), e16534. http://dx.doi.org/10.20952/revtee.v14i33.16534

\begin{abstract}
The purpose of the article is to analyze the features of the pedagogical process of problems and prospects for the development of state formation. The beginning of the third millennium is characterized by globalization of social development, rapprochement of nations, peoples, states, the transition of mankind from industrial to scientific and information technologies, high economic and technological systems, which are largely based on educational and intellectual potential. At the same time, the competition of regions, nations, states, and individual citizens is intensifying. State formation as a pedagogical process has common features and peculiarities for each country, people and society. Accordingly, state formation has its own characteristics. State formation is not just a process for the education system, but has the essential characteristics of the pedagogical and creative process, which absorbs an almost endless palette of conscious, unconscious and unconscious actions of the people and their elite. State formation is a historical process of state building, creation and development of its legal, political, economic, ideological, military, financial and other institutions and ensuring their functioning, which is extremely important in the modern education system. As a result, the main aspects of the pedagogical process of problems and prospects for the development of state formation were described.
\end{abstract}

Keywords: Pedagogical process. Pedagogy. Problems. Prospects of development. State formation. 


\section{RESUMO}

O objetivo do artigo é analisar as características do processo pedagógico de problemas e perspectivas para o desenvolvimento da formação do Estado. O início do terceiro milênio é caracterizado pela globalização do desenvolvimento social, pela reaproximação das nações, povos, Estados, pela transição da humanidade das tecnologias industriais para as científicas e da informação, pelos elevados sistemas econômicos e tecnológicos, que são amplamente baseados no potencial educacional e intelectual. Ao mesmo tempo, a competição de regiões, nações, estados e cidadãos individuais está se intensificando. A formação do Estado como processo pedagógico apresenta características e peculiaridades comuns a cada país, povo e sociedade. Conseqüentemente, a formação do estado tem suas próprias características. A formação do Estado não é apenas um processo para o sistema educacional, mas possui as características essenciais do processo pedagógico e criativo, que absorve uma paleta quase infinita de ações conscientes, inconscientes e inconscientes do povo e de suas elites. A formação do Estado é um processo histórico de construção do Estado, criação e desenvolvimento de suas instituições jurídicas, políticas, econômicas, ideológicas, militares, financeiras e outras e garantia de seu funcionamento, o que é extremamente importante no sistema educacional moderno. Como resultado, foram descritos os principais aspectos do processo pedagógico de problemas e perspectivas para o desenvolvimento da formação do Estado.

Palavras-chave: Formação do Estado. Pedagogia. Perspectivas de desenvolvimento. Problemas. Processo pedagógico.

\section{RESUMEN}

El propósito del artículo es analizar las características del proceso pedagógico de problemas y perspectivas para el desarrollo de la formación estatal. El comienzo del tercer milenio se caracteriza por la globalización del desarrollo social, el acercamiento de naciones, pueblos, estados, la transición de la humanidad de las tecnologías industriales a las científicas y de la información, altos sistemas económicos y tecnológicos, que se basan en gran medida en el potencial educativo e intelectual. Al mismo tiempo, se intensifica la competencia de regiones, naciones, estados y ciudadanos individuales. La formación del Estado como proceso pedagógico tiene rasgos y peculiaridades comunes a cada país, pueblo y sociedad. En consecuencia, la formación del estado tiene sus propias características. La formación del Estado no es solo un proceso para el sistema educativo, sino que tiene las características esenciales del proceso pedagógico y creativo, que absorbe una paleta casi interminable de acciones conscientes, inconscientes e inconscientes de las personas y su élite. La formación del Estado es un proceso histórico de construcción del Estado, creación y desarrollo de sus instituciones legales, políticas, económicas, ideológicas, militares, financieras y de otro tipo y asegurando su funcionamiento, lo cual es sumamente importante en el sistema educativo moderno. Como resultado, se describieron los principales aspectos del proceso pedagógico de problemas y perspectivas para el desarrollo de la formación del Estado.

Palabras clave: Formación estatal. Pedagogía. Perspectivas de desarrollo. Problemas. Proceso pedagógico.

\section{INTRODUCTION}

State formation is a process aimed at actualizing the national idea in the field of public administration, developing and implementing the ideology of state formation, creation and formation of the state as a system of relations and its institutions that should ensure the viability and development of the state. State formation has a pedagogical motive. State formation is a multifaceted process that covers a range of interrelated factors, including natural-geographical, cultural-humanitarian, linguistic, ethno-psychological, spiritual and ideological (mythological and religious), socio-economic, legal, geopolitical, military-defense, etc. reflecting all spheres of society 
and allows you to effectively reveal many qualities in the pedagogical process. State formation is a continuous process. At each stage of state formation, the goals must be set and a strategy for the development of the state must be developed, and the role of public authorities in this process must be determined. Each nation or people has its own special way of creating and organizing social relations and institutions of the state. Unfortunately, the history of our people and statehood is interpreted by anyone and in any way, but in their favor, teaching us who we are, where and where and with whom to go. According to such approaches, history is written outside or in our country on behalf of those who impose and "help" us to draw "correct" conclusions from the past and set priorities for the present and the future. Therefore, the more or less real history of state formation is waiting for its national content and spread. Modern comments and conclusions of those who consider themselves experts in the history of the people, and it, as practice shows, know everything and everything, are based in the vast majority on certain well-known historical events and biographies of famous people, forgetting the feasts of saints - the principle of historicism. is that modern conclusions must be based on the objectivity, complexity (system) and reality (reality) of historical life, and it is and will be multifaceted, contradictory and always in motion. All internal and external connections, patterns and qualitative and quantitative transition from one historical state to another should be considered in the dynamics and with due regard to the views, positions of those people and the time when certain events took place. Stereotyping and stereotyping in the pedagogical process regarding the historical existence of the people, the state and the individual is unacceptable.

Today, there is no consensus among scholars and educators on the essence of state formation, but the analysis of definitions of this concept provides grounds for the conclusion of the interpretation of state formation as a process aimed at creating and building the state and modernizing the system of government. In our opinion, state formation as a management category is a process aimed at actualizing the national idea in the field of public administration, developing and implementing the ideology of state formation, creation and formation of the state as a system of relations and its institutions that should ensure viability and development.

The purpose of the article is to analyze the features of the pedagogical process of problems and prospects for the development of state formation.

\section{METHODOLOGY}

To achieve this goal, our analysis was performed using a number of theoretical methods. These include systems analysis and synthesis, induction and deduction, comparison, classification, generalization and systematization, idealization and abstraction.

\section{RESULTS AND DISCUSSION}

The present society is the path of radical transformations, the state of national security. Modern youth forgets about their national roots, has a low level of knowledge of the history of their native country, so patriotic education is extremely relevant. Further development of society requires the formation of an active, creative personality-patriot, on whose activities spiritual development and well-being depend.

The relevance of educating students' patriotism in society is associated with the existence of certain strata of society that are dissatisfied with the development of the political, economic and social spheres, which are the basis for an ambiguous attitude towards their country. The preservation of the centuries-old traditions of the people, associating them with the heritage of their ancestors is the driving force behind the solution of many political, economic and pedagogical issues. Therefore, the present requires the training of modern patriotic young cadres in various sectors of the economy and government agencies. 
The patriotic education of students is relevant for modern scientists. Analyzing the works of researchers, we can conclude that the formation of patriotism as the main quality of a young person's personality is based on the education of patriotic consciousness, therefore, it characterizes patriotic education as a process that reproduces a person's attitude to his country. The generalization of the above gives reason to believe that the upbringing of patriotism through the history of the formation of the state gives a person's awareness of himself as a citizen. Upbringing through the introduction of the educational aspects of the formation of the state accumulates the socialization of a person in the process of his interpersonal interaction, in the educational process of an educational institution, provides for the implementation of a patriotic molding approach in academic and extracurricular time, as well as the organization of patriotic activities of students in communities. The peculiarities of upbringing in modern conditions are the absence of a mandatory form of its implementation, the special role of the teacher's personality as a coordinator of activities, various approaches to the formation of the content and implementation of upbringing according to the individual and age characteristics of students.

The upbringing space is a multidimensional formation of conditions through which all the factors of upbringing and other factors influence the process of formation, development and selfrealization of the individual. It is this space, where the process of upbringing the personality is carried out, determines its direction and character. So, the sphere of educational space is broader than the education system, it covers and unites the interests of all subjects of society - the community, the authorities, the media, public organizations and public institutions, institutions and organizations involved in the process of civic and patriotic education at the regional level to provide assistance to youth organizations; organizes cooperation and coordination of patriotic public organizations.

The formation of the state and its influence on students as a moral value and a set of sociopolitical relations is a powerful factor and a necessary condition for the protection of national interests, the revival and strengthening of the nation. In the conditions of the current economic, social, spiritual and cultural crisis, the need for patriotic education of the younger generation acquires special relevance. The development of acute competition between socially oriented values and hedonistic ideals at the level of mass consciousness, the impossibility of fully realizing the needs imposed by the media, causes changes at the spiritual level, a distortion of the value system. The imbalance of social reforms led to the spread in society of such negative evaluative and behavioral stereotypes as civic infantilism, individualism and selfishness, which, in turn, led to a drop in trust in state and legal institutions. One of the manifestations of the crisis deformation of consciousness is the value collapse, and the patriotic feelings of young people experience a special transformation. The need for a purposeful state policy in the field of national-patriotic education of young people is due to the need to consolidate the entire society to overcome the challenges facing the country. In the conditions of a crisis state of society and an acute conflict situation, the need to study the effectiveness of the implementation of state policy in the field of national-patriotic education is actualized.

Restoring the system of value regulation of society should become a priority area of measures aimed at resuscitating patriotic education in the country, since in conditions of a high degree of social disintegration and deconsolidation, a crisis of trust and social justice, it is impossible to form true patriotism. Young people spend most of their time on the Internet, without having a reliable foundation of value coordinates that correspond not only to the basic values of society, but also to the principles of its organization and functioning of social relations in it. Therefore, young people are easily influenced by the media and do not always have a positive effect on their behavior and values. Therefore, today we can state that the media are already quite successfully competing with the basic agents of socialization, and the power of the Internet's influence is so great that even the family is not able to withstand the negative influence of its information environment. 
Each school has the goal of the comprehensive development of youth, including through the formation of a sense of cultural and national identity, patriotic views, awakening interest in the culture of the region and local life. Working with children and young people, teachers should form a positive attitude towards human life, Motherland and nature. Parents hope that the school will provide them with education and upbringing with a sense of respect for universal human values. Unfortunately, recently such concepts as patriotism and patriotic education have lost their meaning, they have become commonplace from their frequent use for certain political purposes. Therefore, the role of a teacher acquires particular importance, who must make efforts to teach love for the Motherland.

Each country achieves power primarily by the strength of its individual citizens. For this reason, patriotism means a person's concern for his personal development, physical health, as well as mental, spiritual and religious maturity. Young patriots decide their own destiny, choose the future of their country and nation, therefore it is very important to instill patriotic views, a sense of responsibility for the fate of the state from childhood. Often in everyday life, one can see manifestations of negativity, dishonesty, corruption, political disputes, and the like. This prevents the establishment of patriotic views among both young people and the older generation, so it is necessary to change, not the values themselves, but the form of their transmission, so that citizens do not feel helpless, confused and even indifferent. We need to avoid over-idealization, together look for ways to improve, build a quality world than the one in which we live. We must not be afraid of mistakes and not hide them, because for cognition and awareness of our identity, in addition to the sphere of common values, traditions and experience, the most important thing is cognitive openness, which allows you to creatively combine elements of history with everyday life and the future.

Patriotic education is viewed as the ideal of educating young people based on the democratic, humanistic and pedagogical basis of national consciousness, which is combined with tolerance in relations between people, with truth and justice. Patriotic education is designed to give a new impetus to the spiritual health of the people, the formation of a civil society, which provides for the transformation of public consciousness, moral, legal culture of the individual, the flowering of national identity and is based on the recognition of the priority of human rights. It should stimulate the development of a society that functions on the principles of humanism, freedom, the rule of law, social justice, and guarantees conditions for the growth of the people's well-being. The main task of upbringing is the formation of patriotism, and at the present stage, the problem of the formation of statehood is of particular importance. Patriotic education is a systematic educational activity aimed at fostering a sense of patriotism in pupils, that is, a good becoming to the Motherland and to representatives of a common culture or country. Such upbringing encompasses the development of love for the Motherland, national identity and dignity; respect for the native language, culture, traditions; responsibility for the nature of the home country; the need to contribute to the fate of the Motherland; interest in interethnic communication; the desire to work for the good of the native country, its people. Thus, patriotic education today is relevant both for the education system and for the state as a whole.

The content of patriotic education provides an understanding of social laws and problems of society and ways to solve them; develops the ability to social creativity as a condition for social adaptation, competitiveness and self-realization of the individual in market relations. Patriotic education is implemented as a systematic educational activity aimed at fostering a sense of patriotism and social responsibility in pupils. It includes the development of love for the Motherland, national identity and dignity; respect for the native language, culture, traditions. Patriotism is a feeling of pride in one's homeland, its history, achievements. This desire to make our country more beautiful, richer, stronger, happier - this is the national pride and dignity of the people, united by patriotic feelings as a public cement. Patriotism as a sublime feeling, an irreplaceable value and 
source, the most important motive of socially significant activity, is most fully manifested in a person, a social group that has reached the highest level of spiritual, moral and cultural development. True spiritual patriotism at its core presupposes disinterested, selfless service to the Fatherland up to self-sacrifice. It follows from this that the problem of the socio-pedagogical foundations of the development of patriotic education of student youth in the process of teaching and educational activities in a general education school is relevant and has a complex character.

Formation of a qualitatively new system of education is carried out in the conditions of sharp aggravation of educational problems, strengthening of the negative phenomena in the educational environment. According to sociological and psychological-pedagogical research, a significant part of young people have ideological indifference, passivity, loss of ideals, alienation from the older generation. There is a neglect of education, professional qualifications, a significant decline in students' interest in culture, art, literature, spiritual values. The reasons for this are, first of all, in the economic instability and spiritual disorder of modern society, the decline in living standards of the majority of the population. In the pedagogical literature you can find many interesting materials that contain an analysis of the problems of education, its essence and content in the new sociopolitical and socio-economic conditions. However, the essence of education itself, as the most important task of the education system, remains unchanged and acquires its features in a transformational environment (Karpova, Shtefan, Kovalska, Ionova, Luparenko, 2020; Gurevych, Silveistr, Mokliuk Shaposhnikova, Gordiichuk, Saiapina, 2021; Kryshtanovych, Tiurina, Piechka, Rusyn, Prokopenko, 2021; Mihalache, 2019).

Building an open state integrated into the world's political, economic, scientific, technical, cultural, environmental processes requires policy actors to implement the state-building project and form a national management paradigm of the ability and desire to take into account and study trends in world development, rely on them, and to improve the practice of political governance based on it. One of such tendencies is the symbolization of socio-political relations in the educational process, which means the transformation into a symbol of any action that is consciously carried out by their subject. As a specific form of indirect communication, the symbol, being an integral part of the spiritual, cultural, ideological, political life of society, plays the role of a means of integration and mobilization of human communities. Symbols have always been used when necessary to demonstrate the strength of unity and cohesion of a social group. In a concentrated form, they represent collective ideas and at the same time point to another (sacred) reality. That is, symbols do not reflect social reality, but become reality itself for the community (Zamiralova, Sizikova, Karpunina, Shimanovskaya, Kvitkovskaya, 2020; Suglobov, Orlova, Kalliopin, Katys, Novikov, 2021). Thus, the formation, fixation and reproduction of the nation and the state in the educational process is always based on a system of symbol forms and symbolisms, which through the creation of national symbolic space and competition with symbolic universes of other cultures, states and geopolitical formations. sovereignty. Such a huge creative potential and the ability to generate new meanings, leading to the reformatting of the space of social power relations, actualize the study of the nature of the symbol as a phenomenon of political reality and an instrument of political and managerial influence (Shevchenko, Makhynia, Polishchuk, Sotska, Koval, Grygorenko, 2021; Nikolina, Loshchilova, Aksenov, Lebedeva, Bazarnova, 2021). After all, in the conditions of paradigmatic shifts in the worldview of modern post-industrial society, when the traditional foundations of state regulation of socio-political relations are weakened, the instrumental efficiency of political institutions responsible for the implementation of integrative and teleological functions of the political system decreases. , recourse to the arsenal of non-traditional resources in politics is an urgent requirement of the time.

Dynamic development of the state is impossible without a proper level of legal awareness and legal culture among students. It is the features and nature of pedagogical legal awareness and legal culture are the factors that determine the quality and pace of the state-building process. It can 
be argued that pedagogical legal awareness is the basis for the formation of public demand for the quality of parliamentarism, the proper legal culture of those in power, improving the efficiency of law enforcement and judicial systems, and others.

Unfortunately, the deformations of pedagogical legal consciousness are manifested in the activities of various subjects of state formation - authorities, officials, parties, political leaders. Distortion of legal consciousness is manifested in the degree of fulfillment of the norms of law by the above-mentioned subjects, their attitude to official duties, understanding of their role in democratic transformations, etc.

At the same time, the distortions of pedagogical legal consciousness are gradually overcome under the influence of the general democratization of social relations, by increasing the level of development of civil society institutions. It should be noted that civil society is a certain founder of the rule of law, performs the function of controlling the activities of officials. Civil society essentially embodies the degree of self-organization of the human community on the basis of current legislation and traditions. Thus, the student must realize the value of law as an integral attribute of a democratic state governed by the rule of law. On the other hand, the public legal consciousness must perceive and recognize the instrumental function of law as a means of resolving existing contradictions. The state serves not any abstract purpose, but the establishment of holistic truth, internal, spiritual development of society, and civil society, embodies not only an external means of satisfying the interests of individuals, but the necessary form of civil cooperation, form of service, implementation of effective truth (Prymakova, Krasnoboka, Finin Dobrovolska, Khrypun, Udovychenko, 2021; Shumovetska, Didenko Boreichuk, Balendr, Snitsa, 2021; Vargas, Bizelli, Santos Cruz, 2020).

In turn, the state must create legislative conditions for the development of democratic legal consciousness in order to overcome the vestiges of paternalistic legal consciousness. The paternalistic policy of the state, which keeps society in an underdeveloped, immature state on the principle of "we are your parents, you are our children", should give way to a partnership between the citizen and the government. Then the dictates of inefficient and irresponsible authorities will be replaced by the initiative and self-government of citizens. Note that the state has a number of features of the neo-patrimonial system of government: the presence of ties, the predominance of tradition over law, contempt for existing legislation. Such a system of relations is not mediated by law and in essence contradicts the rule of law with its publicity and openness to the solution of vital social problems. One of the value indicators of the development of democratic social legal consciousness, which influences the formation of the state, is the understanding of freedom by citizens, the ability to use it. In the process of becoming an independent state, the people gained freedom, but unfortunately did not learn to use it, defend and exercise their constitutional rights. That is, public and individual legal consciousness only gradually "gets used" to the democratic dimension of interaction with the state. Real, not declared, freedom is possible only when power serves the law (Basov, Karapkova, Khlopkova, Shnaider, 2021; Kryshtanovych, Zyazyun, Vykhrushch, Huzii, Kalinska, 2021; ).

Determining the features of the influence of students' legal consciousness on state-building processes, it is necessary to take into account the constants of the national character of our people, namely such a feature of it as individualism. This feature is due primarily to the agricultural culture of our people, because due to the fertility of chernozems, the peasant provided his needs through individual labor, which distinguished his work from collective farming. As a result, in the mentality, individualism dominates over collectivism, and personal rights take precedence over universal ones. We emphasize that individualism can play both a positive and a negative role in the context of the development of modern legal consciousness of society and the formation of statehood. On the one hand, this trait influenced the formation of sense of self-worth, contributed to the development of the ability to independently organize personal life - to create a unique private world, thus providing 
a certain degree of freedom. On the other hand, individualism became the cause of the inability of the people to radically solve the problem of their sustainable development, stable existence, to create socio-normative, legal forms of social activity, to protect the first sprouts of statehood.

An important role in the development of legal awareness of society is played by the system of pedagogical education, aimed at the formation of civic qualities of the individual. It is a student who adheres to legal norms is able to become a guarantee of progressive development of a democratic, legal state. Pedagogical education is aimed at fixing in the minds of students the following attitudes, which are a kind of landmarks in everyday life: - respect for law and legality, attitude to them as the highest social values without which it is impossible to realize themselves in a civilized way, protect their rights and freedoms; - the presence of legitimate goals, plans, intentions in life, activities, actions and non-perception of all illegal; - need, desire, skills to behave lawfully guided by stable legal motives; - the presence of unshakable immunity to criminogenic temptations; - the desire to assist law enforcement agencies in solving the crime, to promote the implementation of the principle of inevitability of punishment; - attempts to deter other citizens from committing offenses and encouraging them to behave lawfully; - all possible participation in maintaining law and order at work, at the place of study or residence.

The law itself, as such, has a constant impact on education through various channels and means. Legal influence covers the unity of various forms of law and influence on the consciousness and behavior of students. Legal influence on the student is carried out through two channels:

1) information - with the help of legal norms the state informs the participants of legal relations of their own position on what behavior is such that is allowed, required or prohibited;

2) value-oriented - with the help of law is the assimilation of society of those values that are produced by mankind and passed from generation to generation.

Summing up the role and place of pedagogical legal consciousness in state-building processes, it should be noted that the progressive development of our society in the perception and implementation of constitutional norms will build a European system of relations in the triangle man-society-power. It is on the basis of civilized legal relations that the nation and statehood must develop.

Pedagogical education of patriotism among students through the historical aspects of the formation of the state should be such that innovative methods are inculcated in it. This approach will contribute to the formation of positive motivation among students of educational institutions for patriotic education in the process of extracurricular work. When developing educational and methodological support for the patriotic education of senior students in the process of tourist, search and play activities, attention should be paid to the study of their functional state. This is necessary in order to know how much of the daily and weekly load (including physical) leads to the systematic accumulation of physical fatigue in students, which negatively affects the general health, physical development and physical fitness. This will make it possible to correctly solve the issues of restoring their mental and physical working capacity, strengthening health, improving physical development and increasing physical activity. Their solution is possible provided that new forms and methods of military-patriotic and physical education of the individual are introduced into general educational institutions. This will be facilitated by the development of a network of educational institutions in the state to promote the development of traditions, martial arts horting and the introduction of mobile breaks, physical culture minutes, which are considered unloading, in general educational institutions (Kryshtanovych, Nevmerzhytska, Teletska, Yankovska, Shovsh, 2021; Savchenko, Kiriukha, Potapenko, Dupak, Krasiuk, 2021).

The study of the problem of patriotic education of student youth in general educational institutions is based on the conceptual provisions that the dynamic development of modern education, society, and the state constantly influences the content of patriotic education. This requires new views on the content, forms and methods of patriotic education of the individual; they 
must develop, change and improve in accordance with the social, moral, aesthetic, physical, cultural and spiritual needs of students of general education institutions, as subjects of civil society. The development of their physical condition and the formation of patriotic upbringing must correspond to the modern requirements of the theory and methods of education and be in a state of constant movement, contributes to the formation of a comprehensively developed personality with high patriotic and moral qualities and physical abilities, which are dominant in the development of the values of patriotism and military-patriotic education modern youth.

\section{CONCLUSION}

Each student consciously or subconsciously analyzes the functional essence of political and social life and identifies their real contemporary problems. The fact is that the positive or negative significance of an object, its aspects exists independently of human consciousness. But until the assessment, until the awareness of the phenomenon, the subject does not know about the values or their practical deformation. The student's assessment of democratic processes is through a comparison of the political ideal and their practical implementation in modern realities. According to the classical concept, democratic consolidation involves profound transformations, at least on three levels: behavioral, value and constitutional. According to teachers, its achievement can be said only if:

1) there are no influential political groups left in the police that would not try to undermine the democratic regime or secession;

2) democratic procedures and institutions are perceived by society as the most acceptable mechanisms for regulating social life;

3) political actors "get used" to the fact that all social conflicts comply with the laws, procedures and institutions sanctioned by the new democratic process.

According to these criteria, it is quite difficult to call the state power democratic, because not all value dimensions of this phenomenon are embodied in the practical sphere. All this and much more should be actively covered in the pedagogical process.

The state-building mechanism in its actual application and pedagogical coverage should strive for the highest standards for the practical implementation of social standards of human rights. Nature consists of facts and laws, and in itself is neither moral nor immoral. It is we who apply our standards to nature, and thus introduce morality into the world of nature, despite the fact that we ourselves are part of this world. We were created by nature, and by creating, endowed with the power to change the world, to anticipate and plan for the future, to make far-reaching decisions for which we are morally responsible, because decisions enter the world of nature only with us. Close to the value ideals of the formation and functioning of standards of state formation is the construction of a democratic and legitimate mechanism of political and legal relations and its effective pedagogical coverage.

Modern problems of state formation are due to the factors of transformation of society, the historical realities of the transition from a command system to the conditions of a legitimate democratic state with the embodiment of the rule of law as the dominant legal guarantee. An obstacle to the spiritual and value rooting of the student is social anomie as the most typical result of the destruction of old values without the timely introduction of new ones. Thus, in the modern pedagogical society there is a conglomeration of problems and deviations that create the basis for the transition of value characteristics of state-building standards into anti-value intentions. As a result, the main aspects of the pedagogical process of problems and prospects for the development of state formation were described. 
Authors' Contributions: Kryshtanovych, M.: conception and design, drafting the article, critical review of important intellectual content; Romanova, A.: conception and design, drafting the article, critical review of important intellectual content; Koval, I.: conception and design, drafting the article, critical review of important intellectual content; Lesko, $\mathrm{N}$.: conception and design, drafting the article, critical review of important intellectual content; Lukashevska, U.: conception and design, drafting the article, critical review of important intellectual content. All authors have read and approved the final version of the manuscript.

Ethics Approval: Not applicable.

Acknowledgments: Not applicable.

\section{REFERENCES}

Basov, I. I. ., Karapkova, O. G. ., Khlopkova, V. M. ., \& Shnaider, V. G. . (2021). The use of distance learning technologies in a pedagogical university: a comparative analysis of students' attitude in 2020-2021. Laplage in Journal, 7(3B), p.677684. https://doi.org/10.24115/S2446-6220202173B1612p.677-684

Gurevych, R., Silveistr, A., Mokliuk M., Shaposhnikova, I., Gordiichuk, G., \& Saiapina, S. (2021). Using Augmented Reality Technology in Higher Education Institutions. Postmodern Openings, 12(2), 109-132. https://doi.org/10.18662/po/12.2/299

Karpova, L., Shtefan, L., Kovalska, V., Ionova, O., \& Luparenko, S. (2020). Information-Educational Environment as a Condition of Formation of Gifted Children's Informational-Digital Competence. Postmodern Openings, 11(2 Supl 1), 60-78. https://doi.org/10.18662/po/11.2Sup1/179

Kryshtanovych, M. ., Nevmerzhytska, O. ., Teletska, L. ., Yankovska, I. ., \& Shovsh, K. . (2021). Professional competence of future primary school teachers in the context of the covid19 pandemic. Laplage Em Revista, 7(3A), p.463-469. https://doi.org/10.24115/S2446-6220202173A1440

Kryshtanovych, M. ., Zyazyun, L. ., Vykhrushch, N. ., Huzii, I. ., \& Kalinska, O. . (2021). Determinação dos principais componentes da formação da competência profissional para alunos. Laplage Em Revista, 7(3B), p.1-8.

https://doi.org/10.24115/S2446-6220202173B1479

Kryshtanovych, S. ., Tiurina, T. ., Piechka, L., Rusyn, H. ., \& Prokopenko, A. . (2021). Modeling the process of ordering the main obstacles to the professional competence of future teachers. Laplage Em Revista, 7(3A), p.470-479. https://doi.org/10.24115/S2446-6220202173A1441

Mihalache, I. C. (2019). Health State of Human Capital in the Economic Theory. Postmodern Openings, 10(4), $182-192$. https://doi.org/10.18662/po/102

Nikolina, V. ., Loshchilova, A. ., Aksenov, S. ., Lebedeva, I. ., \& Bazarnova, N. . (2021). Development of the methods for the class teacher effectiveness assessment . Laplage in Journal, 7(3A), p.644-664. https://doi.org/10.24115/S2446$\underline{6220202173 A 1473 p .644-664}$

Prymakova, V., Krasnoboka, T., Finin H., Dobrovolska, V., Khrypun, D., \& Udovychenko, I. (2021). Distance Learning and Globalization Processes in the Postmodern World. Postmodern Openings, 12(2), 259-273.

https://doi.org/10.18662/po/12.2/307

Savchenko, L. O., Kiriukha, K. I., Potapenko, O. B., Dupak, N. V., \& Krasiuk, I. A. (2021). The formation of a civil responsibility of high school students in the context of specialized training. Revista Tempos E Espaços Em Educação, 14(33), e16104. https://doi.org/10.20952/revtee.v14i33.16104

Shevchenko, L., Makhynia, N., Polishchuk, G. ., Sotska, H. ., Koval, V., \& Grygorenko, T. . (2021). The Training of Future Teachers for Innovative Teaching Activities. Postmodern Openings, 12(1), 21-37.

https://doi.org/10.18662/po/12.1/243

Shumovetska, S., Didenko O., Boreichuk, D., Balendr, A., \& Snitsa, T. (2021). Pedagogical Conditions of Organizational Culture Formation of Future Border Guard Officers. Postmodern Openings, 12(1Sup1), 90-112.

https://doi.org/10.18662/po/12.1Sup1/273

Suglobov, A. E., Orlova, K. S., Kalliopin, A. K., Katys, P., \& Novikov, A. V. (2021). Intellectual property policy of universities: specific regulation. Revista Tempos E Espaços Em Educação, 14(33), e16155.

https://doi.org/10.20952/revtee.v14i33.16155

Vargas, T. C., Bizelli, J. L., \& Santos Cruz, J. A. (2020). Quality in education: what's the suitable funding to the basic education?. Revista Tempos E Espaços Em Educação, 13(32), 1-17. https://doi.org/10.20952/revtee.v13i32.13625 
Zamiralova, T. A., Sizikova, V. V., Karpunina, A. V., Shimanovskaya, Ya. V., \& Kvitkovskaya, A. A. (2020).Influence of university advertising activities on competitiveness in the educational services market. IIOAB Journal, 11(S3), 49-51.

Received: 31 July 2021 | Accepted: 22 September 2021 | Published: 21 October 2021 